\title{
Organic geochemical study of mineralization in the Keweenawan Nonesuch Formation at White Pine, Michigan
}

\author{
EILEen S. Ho, Philip A. Meyers and JefFrey L. Mauk \\ Department of Geological Sciences, The University of Michigan, 1006 C.C. Little Building, \\ Ann Arbor, MI 48109-1063, U.S.A.
}

(Received 7 November 1989; accepted 22 May 1990)

\begin{abstract}
The role of organic matter in the formation of metal ores has been investigated in the Nonesuch Formation at White Pine, Michigan. Organic matter in mineralized strata was characterized by isotopic, molecular and spectrophotometric procedures and compared to organic matter in non-mineralized rocks. Samples from the White Pine copper mine contain little organic carbon in comparison to samples from non-mineralized sections of the Nonesuch Formation. Residual organic matter in mine samples is depleted in solvent-extractable matter, is relatively aromatic in character, and appears to be thermally overmature, yet no difference in carbon isotopic contents exists between kerogen isolated from mineralized and non-mineralized rocks. Comparisons suggest that oxidation of organic matter was involved in the reduction of oxidized metalliferous brines to precipitate copper sulfides and native copper and silver in this setting.
\end{abstract}

Key words-Nonesuch Formation, Proterozoic, FTIR spectroscopy, carbon isotopes, copper mineralization, kerogen

\section{INTRODUCTION}

Metallic ore deposits are commonly found associated with rock strata having elevated amounts of organic matter, leading to the implication that the organic matter was involved in formation of the mineralized strata. Formation of ore deposits requires concentration of metals above their crustal levels. A process which can achieve this enrichment involves migration of heated water through layers of rock. The hot water leaches trace amounts of minerals from the country rock and transports them to a site in which deposition occurs. Organic matter can participate in the formation of ore deposits by causing precipitation of the minerals from the migrating solution through processes which involve the oxidation of organic matter. As an example, Püttmann et al. (1988) document the loss of extractable aliphatic hydrocarbons and the sulfidation of aromatic hydrocarbons which accompany the deposition of copper and silver ores in the Permian Kupferschiefer in Poland.

\section{SAMPLES AND PROCEDURES}

\section{Geologic settings and samples}

The Nonesuch Formation of northern Michigan was deposited under a lake created by rifting of the North American craton during the Keweenawan Age ( ca $1.1 \mathrm{Ga}$ ) of the Middle Proterozoic Era. The formation contains sandstones, siltstones, shales and minor carbonate laminites. Organic carbon concentrations reach as high as $3 \%$ by weight in the siltstones and shales. The basal strata are organized into units called the Parting Shale, the Upper Sand and the Upper Shale (Fig. 1). As summarized by Barghoorn et al. (1965) and Imbus et al. (1988), the section represents an evolution of the depositional setting from marginal lacustrine to deep lacustrine to fluvial lacustrine. Euxinic shales and siltstones form the majority of the lithologies and average $180 \mathrm{~m}$ in thickness.

Copper-rich solutions are believed to have migrated into the Nonesuch Formation where interaction with the organic-rich strata precipitated copper-iron sulfides and native copper and silver (Wiese, 1973; Kelly and Nishioka, 1985). Because copper mineralization is generally restricted to the base of the Nonesuch Formation and to the top of the underlying Copper Harbor Conglomerate, the migrating fluids are believed to have entered the Formation from below (White, 1971). Although the Nonesuch Formation is extensive regionally, copper mineralization reaches ore grades only locally in the vicinity of the White Pine Mine (Ensign et al., 1968).

We obtained mineralized rock samples from within the White Pine Mine from below, at, and above the contact between the Nonesuch Formation and the Copper Harbor Conglomerate. The strata sampled include the Lower Sandstone, the Domino Shale and the Thinly Shale (Fig. 1). Active petroleum seeps occur locally in the mine (cf. Eglinton et al., 1964; Barghoorn et al., 1965); our samples were selected to avoid as much as possible the migrated organic matter introduced by these seeps. 


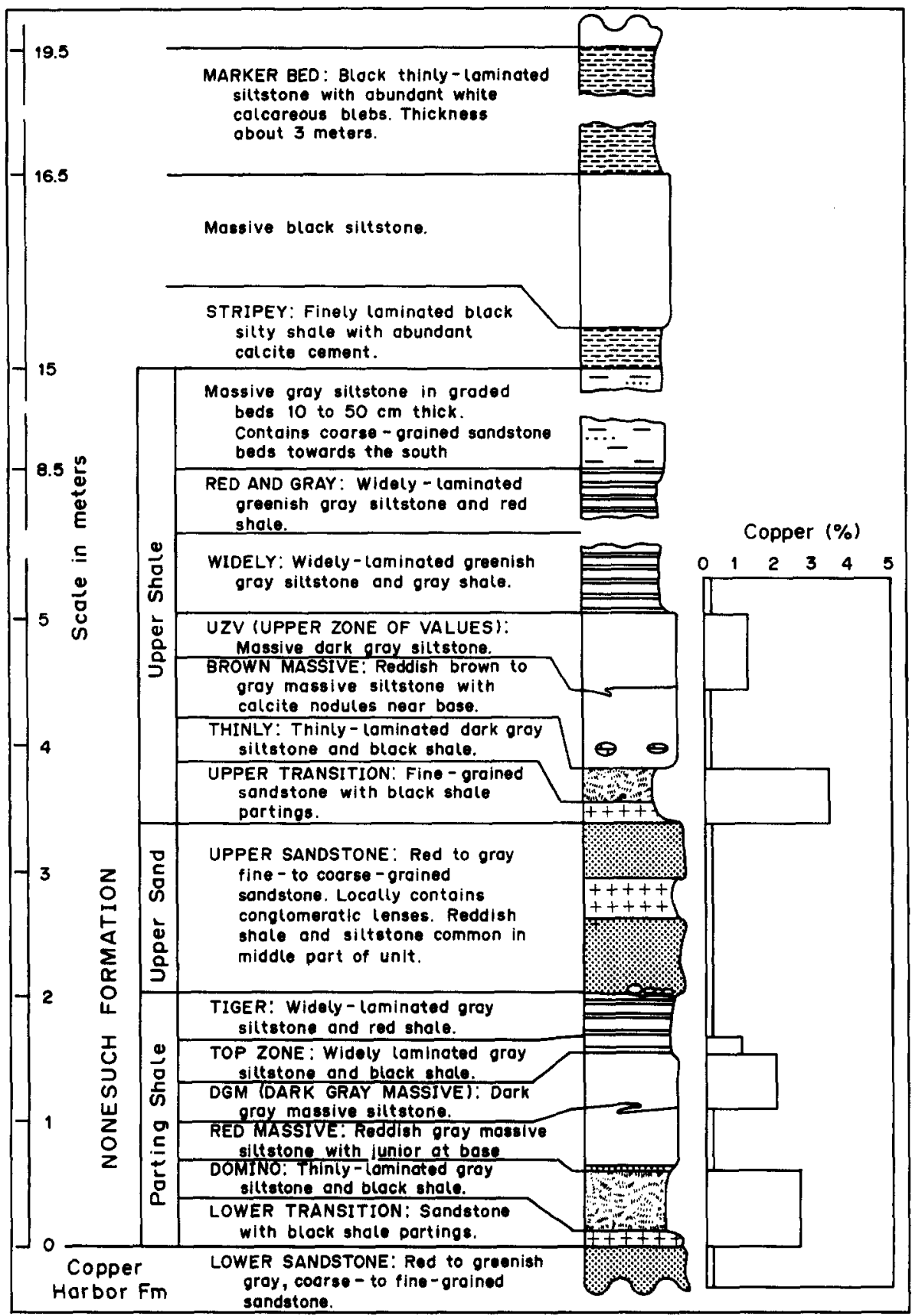

Fig. 1. Stratigraphic column of the contact between the upper portion of the Copper Harbor Formation and the lower portion of the Nonesuch Formation in the region of the White Pine Mine, northern Michigan.

\section{ANALYTICAL PROCEDURES}

Organic carbon concentrations and isotopic contents. Organic carbon concentrations were determined by removing carbonates from dried and ground samples with $3 \mathrm{~N} \mathrm{HCl}$ and measuring the amount of residual carbon with a Hewlett-Packard 185B CHN analyzer. Measurable amounts of nitrogen were rarely present, precluding determination of organic matter $\mathrm{C} / \mathrm{N}$ values. Organic carbon stable isotope ratios were obtained from carbonate-free samples using a VG Micromass 602 mass spectrometer and are reported relative to the PDB standard. Rock-Eval analyses were done with a Delsi Nermag Rock-Eval II instrument.

Solvent extraction and analysis. Extractable matter was obtained from dried and ground samples by Soxhlet extraction using a mixture of toluene and methanol, 3/1, and refluxing for $48 \mathrm{~h}$. Because so little extract was obtained from the samples, it was not fractionated prior to analysis. The total extracted 
material was analyzed using a Hewlett-Packard 5830 FID gas chromatograph equipped with a $20 \mathrm{~m} \mathrm{SE-54}$ capillary column and a splitless injection system. The column was temperature-programed from 120 to $270^{\circ} \mathrm{C}$ at $6^{\circ} \mathrm{C} / \mathrm{min}$, and hydrogen was used as the carrier gas.

Kerogen isolation and analysis. Ground samples of rock were solvent-extracted and then digested with $\mathrm{HCl}$ and $\mathrm{HF}$ to isolate the kerogen. During kerogen isolation from samples of the Lower Sandstone, floating dark-colored matter was obtained after the rock had been dissolved. This was collected and analyzed separately from the bulk kerogen from these samples.

After the insoluble residue from the rock dissolution was oven-dried, it was analyzed by Fourier transform infrared (FTIR) spectroscopy. Transmittance of the kerogen dispersed in pressed $\mathrm{KBr}$ pellets was measured from 4000 to $400 / \mathrm{cm}^{-1}$ using a Nicolet 5-DX spectrometer.

\section{RESULTS AND DISCUSSION}

Rock samples from mineralized units in the White Pine Mine contain little organic matter (Table 1), whereas non-mineralized sections of the Nonesuch Formation approach $3 \%$ organic carbon (Imbus et al., 1988). The samples from the Domino unit of the Parting Shale, near the base of the mineralized zone, have an average organic carbon content of $0.17 \%$, and the samples from the Thinly Unit of the Upper Shale contain an average of $0.26 \%$ by weight. Concentrations of total solvent-extractable material in one Lower Sandstone sample (11 ppm) and in the Thinly Shale samples (av. $24 \mathrm{ppm}$ ) are low for petroleum source rocks (Tissot and Welte, 1984, p. 177). In contrast, extractions of non-mineralized core and surface outcrop samples indicate that portions of the Nonesuch Formation which overlie the ore-bearing strata are hydrocarbon-rich (Hieshima et al., 1989). Two of the Lower Sandstone samples (WPM88-190,192) have very high extract yields and appear to be oil-stained.

Organic carbon in kerogen isolated from both the Thinly Shale and the Lower Sandstone is isotopically light, having $\delta^{13} \mathrm{C}$ values between -34 and $-31 \%$ (PDB). These values are similar to those reported by Barghoorn et al. (1965) for kerogen from a mine sample and by Imbus et al. (1988) for nonmineralized samples. The mineralization process and postulated oxidation of organic carbon evidently did not cause an isotopic shift. One sample of the Lower Sandstone, WP-8, gave a markedly heavier isotope ratio of $-23.95 \%$. This sample may have contained some residual carbonate carbon, inasmuch as its measured "organic" carbon value of $0.35 \%$ seems high for a sandstone having little extractable matter. Barghoorn et al. (1965) show that carbonate carbon has $\delta^{13} \mathrm{C}$ values of $c a-4 \%$ (PDB) in the Nonesuch; a small undissolved fraction of this isotopically heavy carbon could markedly affect the "organic" carbon isotope ratio.

Comparison of chromatograms of the total extractable material from mineralized rock and of the extractable aliphatic hydrocarbon fraction from samples of non-cupriferous Nonesuch Formation away from the mine area reveals important differences (Fig. 2). Although some of the peaks in the total extract trace may not be hydrocarbons, these differences are significant. Whereas the non-cupriferous extract is dominated by a range of $n$-alkanes, the pattern from the mineralized sample contains few of these hydrocarbons. Instead, the distribution resembles those shown for hydrothermally altered basal rocks from the Kupferschiefer (Püttman et al., 1988), in which oxidation of aliphatic organic matter by mineral-bearing fluids is postulated.

Rock-Eval pyrolyses of mineralized samples were generally not informative because of their low contents of organic matter. Two samples, one from the Parting Shale and one from the Upper Shale, gave useful data. Their similar $\mathrm{HI}$ and OI values of $70 \mathrm{mgHC} /$ gTOC and $40-50 \mathrm{mgCO}_{2} / \mathrm{gTOC}$, respectively, are typical of thermally degraded organic matter in which source distinctions have been destroyed. $T_{\max }$ values, are in the 450 to $460^{\circ} \mathrm{C}$ range, suggesting that the rocks have experienced heating not much higher than the $\mathrm{ca} 100^{\circ} \mathrm{C}$ indicated by sulfide minerals (Brown, 1971) and fluid inclusion studies (Nishioka, 1983).

Table 1. Summary of analytical results from samples of the Nonesuch Formation from the White Pine Mine

\begin{tabular}{llccc}
\hline Sample & Stratum & $\begin{array}{c}\delta{ }^{13} \mathrm{C} \\
(\% \circ \mathrm{PDB})\end{array}$ & $\begin{array}{c}\mathrm{C}_{\text {org }} \\
(\%)\end{array}$ & $\begin{array}{c}\text { Extract yield } \\
\text { (ppm) }\end{array}$ \\
\hline WP-5 & Thinly Shale & ND & 0.21 & ND \\
WP-6 & Thinly Shale & -31.32 & 0.47 & 49.6 \\
WP-7 & Thinly Shale & -31.82 & 0.16 & 26.7 \\
WP-9 & Thinly Shale & -33.45 & 0.25 & 24.5 \\
WP-10 & Thinly Shale & -33.58 & 0.19 & 18.7 \\
WPM88-024 & Thinly Shale & -33.50 & ND & 19.4 \\
WPM88-025 & Thinly Shale & -33.53 & ND & 2.9 \\
WP-3 & Domino Shale & ND & 0.08 & ND \\
WP-4 & Domino Shale & ND & 0.35 & ND \\
WP-11 & Domino Shale & ND & 0.07 & ND \\
WP-8 & Lower Sandstone & -23.95 & 0.35 & 11.3 \\
WPM88-190 & Lower Sandstone & -33.35 & ND & 1613.7 \\
WPM88-192 & Lower Sandstone & -33.41 & ND & 144.9 \\
\hline
\end{tabular}

$\mathrm{ND}=$ not determined 


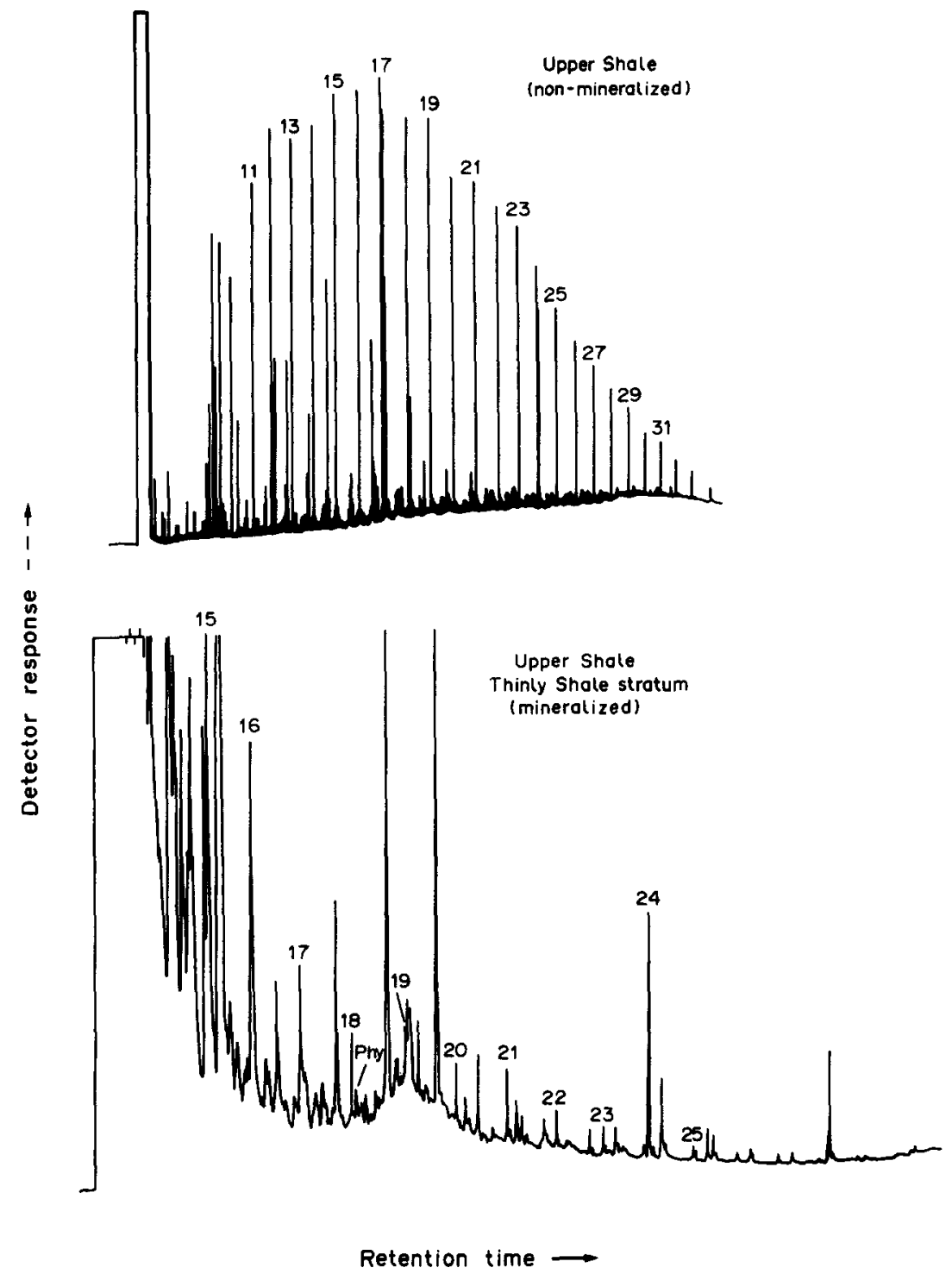

Fig. 2. Capillary gas chromatograms of total extractable material from a non-mineralized section of the Upper Shale (top) and of the extractable hydrocarbons from a mineralized section of the Thinly Shale (bottom). The Upper Shale chromatogram was kindly provided by L. Pratt, Indiana University.

The FTIR spectra of kerogen isolated from samples of the Thinly Shale and the Lower Sandstone show characteristic patterns for the two strata (Fig. 3). FTIR patterns of other samples are similar to these representatives of the two rock types. The spectra of the floatable kerogenous material isolated from the Lower Sandstone during mineral dissolution differ from those of the bulk kerogen (Fig. 3).

The i.r. spectral band at $1644 \mathrm{~cm}^{-1}$, which corresponds to aromatic $\mathrm{C}=\mathrm{C}$ bond stretching, is prominent in the kerogen spectra from both the Thinly and the Lower Sandstone. The spectral bands between wavenumbers 2965 and $2850 \mathrm{~cm}^{-1}$, corresponding to aliphatic $\mathrm{C}-\mathrm{H}$ bond stretching of methylene and methyl groups, are significant only in the spectra of kerogen from the Lower Sandstone samples. These data imply that the bulk kerogens in these two strata have considerable aromatic character, with the kerogen from the Lower Sandstone being more aliphatic in character.

The i.r. spectra of the floatable Lower Sandstone kerogens are characterized by strong aliphatic $\mathrm{C}-\mathrm{H}$ bands and an absent or notably weaker aromatic $\mathrm{C}=\mathrm{C}$ band. The highly aliphatic character of this material, along with petrographic evidence of porefilling organic matter and high extract yields in the Lower Sandstone strata, suggests that the floatable material may be the residue of petroleum that migrated through this sandstone layer.

None of these spectra displays evidence of $\mathrm{C}=\mathrm{O}$ bond stretching, implying that the kerogen of these samples contains few carbonyl-oxygen-containing functional groups. The inferred oxidation of this organic matter evidently took the form of aromatiz- 


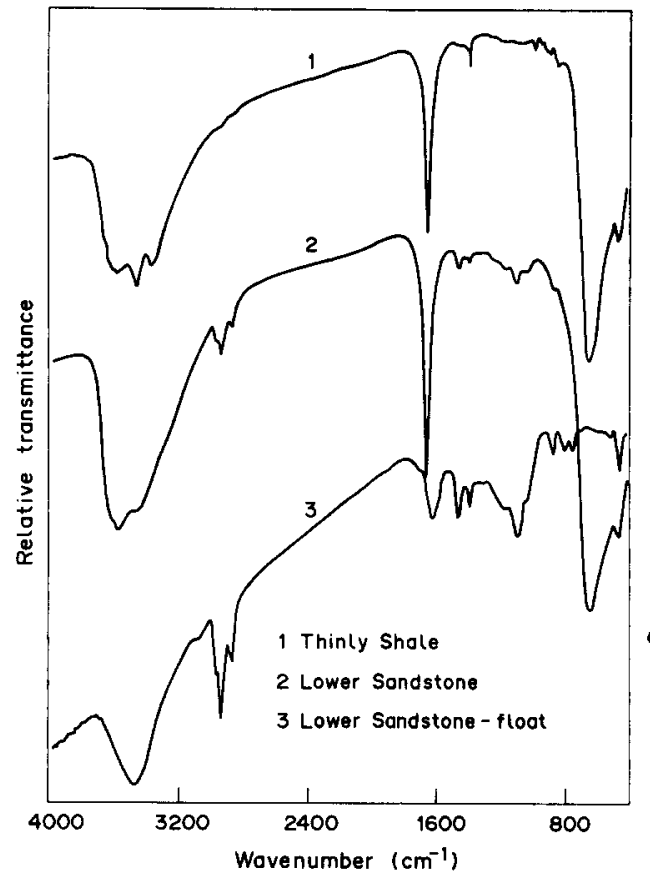

Fig. 3. FTIR spectra of kerogen isolated from the Thinly Shale (top) and the Lower Sandstone (middle) and of floatable organic matter released by dissolution of the Lower Sandstone during kerogen isolation (bottom).

ation, not incorporation of oxygen into the kerogen matrix. The broad bands centered around $3450 \mathrm{~cm}^{-1}$ in all samples may contain possibly significant information about the presence or absence of other functional groups, but it is masked by the difficult-to-avoid absorption by water in this portion of the infrared spectrum.

\section{SUMMARY AND CONCLUSIONS}

Characterization of organic matter from mineralized and non-mineralized sections of the Nonesuch Formation of northern Michigan provides inferences about the role of organic matter in ore formation. In the White Pine copper deposits, which are hosted in this Proterozoic sedimentary sequence, organic matter appears to have been degraded relative to non-cupriferous portions of the formation. The lowered concentrations of organic carbon and of solvent-extractable material in the mineralized samples are consistent with the hypothesis that oxidation of organic matter occurred during the deposition of copper from metal-bearing solutions. The absence of a significant contribution of saturated hydrocarbons, such as $n$-alkanes, to the total extractable material and the aromatization of kerogen in mineralized rocks are additional support for this hypothesis. Further investigations of how the amounts and types of organic matter relate to the abundance and occurrence of copper mineralization are needed to ascertain whether organic matter was an active participant in the redox precipitation of the ores in these rocks.

Many metallic ores, like those in this study, are associated with rocks having enhanced concentrations of organic carbon. In some settings, organic matter can be oxidized to carbon dioxide, which then combines with metallic cations to precipitate carbonate minerals (Okita et al., 1988; Spirakis and Heyl, 1988). Organic matter may also act as a reductant of metal sulfates carried in solution by hydrothermal waters or warm brines (Anderson and Macqueen, 1982; Hatch et al., 1986; Macqueen, 1986; Püttmann et al., 1988). The reduction of the sulfates results in the oxidation of organic matter, and it may lead to the precipitation of less-soluble sulfides and native metals, such as those present in the Nonesuch Formation copper-silver ore body studied here.

Note added in proof - Some confusion exists in the stratigraphic nomenclature of the Nonesuch Formation. In this paper, the Michigan workers define "Upper Shale" according to local mine terminology as a major division of the basal strata, including the Thinly Shale (Fig. 1). The Indiana workers define "Upper Shale" as the non-mineralized strata which overlie the locally mineralized, basal strata (i.e. units above and including Stripey in Fig. 1). Both usages are reflected accordingly in Fig. 2.

Acknowledgements-We thank the White Pine Copper Company for allowing access to its property. Field work at White Pine was supported by a grant from Amoco Oil Company, We are grateful to W. C. Kelly for sharing with us his knowledge and understandings of the geologic setting we studied. Rock-Eval analyses were kindly provided by J. G. Palacas and L. Pratt shared her unpublished extractable organic matter information with us. This work has been supported, in part, by a grant from the U.S. National Science Foundation (EAR-8707353).

\section{REFERENCES}

Anderson G. M. and Macqueen R. W. (1982) Ore deposit models-6. Mississippi Valley-type lead-zinc deposits. Geosci. Canada 9, 108-117.

Barghoorn E. S., Meinschein W. G. and Schopf J. W. (1965) Paleobiology of a Precambrian shale. Science 148, 461-472.

Brown A. C. (1971) Zoning in the White Pine copper deposit, Ontonagon County, Michigan. Econ. Geol. 66, 543-573.

Eglinton G., Scott P. M., Belsky T., Burlingame A. L. and Calvin M. (1964) Hydrocarbons of biological origin from a one-billion-year-old sediment. Science 145, 263-264.

Ensign C. O. Jr, White W. S., Wright J. C., Patrick J. L., Leone R. J., Hathaway D. J., Trammell J. W., Fritts J. J. and Wright T. L. (1968) Copper deposits in the Nonesuch Shale, White Pine, Michigan. In Ore Deposits of the United States 1933-1967 (Graton-Sales Volume, Edited by Ridge J. D.), Vol. 1, pp. 459-488. Am. Inst. Mining, Metallurgy and Petrol. Engng, New York.

Hatch J. R., Heyl A. V. and King J. D. (1986) Organic geochemistry of hydrothermal alteration, basal shale and limestone beds, Middle Ordovician Quimbys Mill Member, Platteville Formation, Thompson-Temperly zinc-lead mine, Lafayette County, Wisconsin. In Organics and Ore Deposits (Edited by Dean W. H.), pp. 93-104. Denver Region. Explor. Geol. Soc., Denver.

Hieshima G. B., Zaback D. A. and Pratt L. M. (1989) Petroleum potential of Precambrian Nonesuch Formation. Am. Assoc. Petrol. Geol. Bull. 73, 363 (abs). 
Imbus S. W., Engel M. H., Elmore R. D. and Zumberge J. E. (1988) The origin, distribution and hydrocarbon generation potential of organic-rich facies in the Nonesuch Formation, Central North American Rift System: a regional study. Org. Geochem. 13, 207-219.

Kelly W. C. and Nishioka G. K. (1985) Precambrian oil inclusions in late veins and the role of hydrocarbons in copper mineralization at White Pine, Michigan. Geology 13, 334-337.

Macqueen R. W. (1986) Origin of Mississippi Valley-type lead/zinc ores by organic matter-sulfate reactions: the Pine Point example. In Organics and Ore Deposits (Edited by Dean W. E.), pp. 151-164. Denver Region. Explor. Geol. Soc., Denver.

Nishioka G. K. (1983) Origin of late veins in the White Pine copper deposit, northern Michigan. MS Thesis, Univ. Michigan. Ann Arbor.

Okita P. M., Maynard J. B., Spiker E. C. and Force E. R. (1988) Isotopic evidence for organic matter oxidation by manganese reduction in the formation of stratiform manganese carbonate ore. Geochim. Cosmochim. Acta 52, 2679-2685.

Püttmann W., Hagemann H. W., Merz C. and Speczik S. (1988) Influences of organic material on mineralization processes in the Permian Kupferschiefer Formation, Poland. Org. Geochem. 13, 357-363.

Spirakis C. S. and Heyl A. V. (1988) Possible effects of thermal degradation of organic matter on carbonate paragenesis and fluorite precipitation in Mississippi Valley-type deposits. Geology 16, 1117-1120.

Tissot B. P. and Welte D. H. (1984) Petroleum Formation and Occurrence, 2nd Edn. Springer-Verlag, Berlin.

Wiese R. F. Jr (1973) Mineralogy and geochemistry of the Parting Shale, White Pine, Michigan. Econ. Geol. 68, 317-331.

White W. S. (1971) A paleohydrologic model for the mineralization of the White Pine copper deposit, northern Michigan. Econ. Geol. 66, 1-13. 